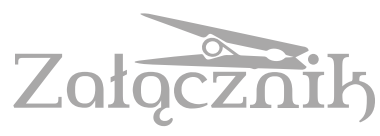

Uznanie autorstwa-Użycie niekomercyjne-Bez utworów zależnych

\title{
THE GREAT FIRE OF LONDON \\ AS A MEMORY SITE (LIEU DE MÉMOIRE)
}

ANNA MARIA TOMCZAK

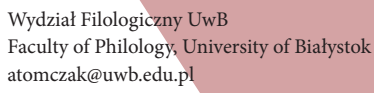

Wydział Filologiczny UwB

Faculty of Philology, University of Białystok atomczak@uwb.edu.pl

It was the appearance of the English translation of Maurice Halbwachs's posthumous La mémoire collective in 1980, simultaneously in New York and Chicago, that gave impetus to wide-reaching interdisciplinary research on social frameworks of memory which, in due course, led to the so-called 'memory boom'. No longer viewed narrowly as the faculty of an individual, memory started to be studied in its public, political and cultural aspects. From being 'a topic for poets' 2 it transformed into a domain of study and social, cultural and political force. Believing the current preoccupation with memory to be a reaction to technological development and the unprecedented pace at which new information is delivered and then quickly forgotten, Andreas Huyssen writes:

My hypothesis here is that we try to counteract this fear and danger of forgetting with survival strategies of public and private memorialization. The turn toward memory is subliminally energized by the desire to anchor ourselves in a world characterized by an increasing instability of time and the fracturing of lived space ${ }^{3}$.

1 A. Whitehead, Memory, London - New York 2009, p. 3.

2 A. Huyssen, Present Pasts: Urban Palimpsests and the Politics of Memory, Stanford 2003, p. 2.

3 Idem, Present Pasts: Media, Politics, Amnesia, „Public Culture” 2000, Vol. 12, No. 1, p. 28. 
In what follows I would like to concentrate on the practices of memorialization with regard to the Great Fire of London of 1666, treating the event as a 'memory site' or lieu de mémoire.

\section{THE CONCEPT OF LIEUX DE MÉMOIRE OR MEMORY SITE}

The idea of lieux de mémoire (memory sites or sites of memory) ${ }^{4}$, introduced into broadly understood humanities by the French historian Pierre Nora, stems from the relationship between history and memory. The concept was explained, discussed and exemplified in a multi-volume Les Lieux de Mémoire, edited and partly written by Nora, published between 1984 and 1992, with the English translation following as Realms of Memory (1996-1998). Deemed at the start of the twenty-first century as 'one of the most influential ventures in cultural history in the last twenty years ${ }^{5}$, Nora's renowned work has proved extremely influential. It has aimed at creating an inventory of memory sites where French national identity crystallizes itself symbolically, whereas the notion of lieux de mémoire has been used worldwide as an analytical tool for tracing the intertwining trajectories of collective identities and cultural memory.

Nowhere in his publications does Nora provide a clear definition of memory sites ${ }^{6}$. Instead, he explains: 'The moment of lieux de mémoire occurs at the same time that an immense and intimate fund of memory disappears, surviving only as a reconstituted object beneath the gaze of critical history', adding: 'lieux de mémoire are fundamentally remains, the ultimate embodiments of a memorial consciousness that has barely

${ }^{4}$ In English language publications both terms are used as the translation of the French term lieux de mémoire.

5 J. Winter, The Memory Boom in Contemporary Historical Studies, „Raritan” 2001, Vol. 21, No. 1, p. 52.

6 On how beautiful but imprecise Nora's writing is see: B. Schwarz, Memory, Temporality, Modernity. Les Lieux de memoire, [in:] Memory: Histories, Theories, Debates, eds. S. Radstone, B. Schwarz, New York 2010, p. 41-58.

7 P. Nora, Between Memory and History: Les Lieux de Mémoire, transl. M. Roudebush, „Representations” 1989, No. 26, Special Issue: Memory and Counter-Memory, p. 12. 
survived in a historical age that calls out for memory because it has abandoned it's. In Nora's understanding, memory sites may be portable or sizeable, like books and paintings, for example Cezanne's Mont Sainte-Victoire and Proust's Remembrance of Things Past, or topographical, like the places of important battles. They may be sites of pilgrimage or cemeteries (e.g. Verdun, Lourdes and Sacre-Coeur), or events (e.g. The Tour de France), but in each lieu three aspects always co-exist: material, symbolic, and functional. The material aspect refers to the site's tangible existence, its concrete form. The symbolic aspect reflects its connotative meaning, while the functional aspect, or the role that lieux de mémoire fulfil, may be multifold. For example, the role of memory sites is to educate, arouse patriotic feelings, raise consciousness but also legitimize the existing order. In Nora's own words, lieux de mémoire 'anchor, condense, and express the exhausted capital of our collective memory ${ }^{9}$ and their most fundamental purpose is 'to block the work of forgetting, to establish a state of things, to immortalize death, to materialize the immaterial [...] to capture a maximum of meaning in the fewest of signs ${ }^{\prime 10}$. Societies and communities decree and cherish memory sites to forge collective identity. Linked by an invisible thread, such objects, places, and works of art establish a strong bond between present and former generations, bringing together the communal and the individual, the living and the dead. As David Lowenthal notes: 'Ability to recall and identify with our own past gives existence meaning, purpose and value' $^{\prime 1}$, and sites of memory are a convenient shortcut on the way. They are understood to be 'almost all forms of the past tangibly felt in the present'12 which serve to preserve our identities through a deliberate will to remember and which function as 'signs of distinction and of group membership'13. In Nora's poetic description, they are 'moments of history torn away from

\footnotetext{
8 Ibidem.

9 Ibidem, p. 24.

10 Ibidem, p. 19.

${ }_{11}$ D. Lowenthal, The Past is a Foreign Country, Cambridge 2003, p. 41.

12 A. Szpociński, Sites and Non-Sites of Memory, transl. A. Warso, „Teksty Drugie" 2016, Vol. 1, Special Issue - English Edition, p. 245.

13 P. Nora, op. cit., p. 12.
} 
the movement of history, then returned; no longer quite life, not yet death, like shells on the shore when the sea of living memory has receded ${ }^{14}$.

Always deliberately selected and institutionalized, memory sites are a replacement of 'true' memory, becoming limitless theatres of commemoration. What societies decide to remember (i.e. what they designate as memory sites) and how they wish to remember their past depends to a large extent on organized forms of remembering and on various authorities and decision takers. For the British society, the Great Fire of London is a memory site in all three aspects - material, symbolic and functional - with considerable potential for metamorphosis.

\section{THE GREAT FIRE OF LONDON: MATERIAL ASPECT}

Predicted by various clairvoyants, soothsayers and even one mathematician George Wharton ${ }^{15}$, who all believed the combination of three sixes in the year 1666 a particularly bad omen, the Great Fire of London ${ }^{16}$ started after midnight on the $2^{\text {nd }}$ September 1666. As was established much later, one of the baking ovens in Thomas Farriner' ${ }^{17}$ bakery in Pudding Lane was not properly put out for the night. Its heat caused sparks to ignite fuel which had been left close to the oven for the next day's baking, and then inflamed the baker's wooden house. Originally, the fire's danger was underestimated. Thomas Bludworth, the then Lord Mayor of London, when called to the scene, seemed quite unconcerned and was heard commenting: 'Pish! A woman might piss it out ${ }^{18}$. Afterwards, he went back to sleep. Yet, within hours large sections of England's capital burned to the ground. A combination

14 Ibidem.

15 See: A. Tinniswood, By Permission of Heaven: the Story of the Great Fire of London, London 2004, p. 19; E. N. Hooker, The purpose of Dryden's Annus Mirabilis, „Huntington Library Quarterly” 1946, Vol. 10, No 1, p. 56.

${ }_{16}$ For basic facts concerning the Great Fire see: https://www.historylearningsite. co.uk/stuart-england/the-great-fire-of-london-of-1666/ [accessed: 10.02.2019].

${ }_{17}$ Different sources provide different spellings: 'Farynor', 'Faryner', or 'Farriner'.

18 Quoted after: Ch. Heyl, A Miserable Sight. The Great Fire of London (1666), [in:] Fiasko - Scheitern in der Frühen Neuzeit: Beitraege zur Kulturgeschichte des Misserfolgs, eds. S. Brakensiek, C. Claridge, Bielefeld 2015, p. 111. 
of factors played a decisive role: a very hot and dry summer which had made London's wooden houses particularly vulnerable, a strong wind blowing from the east which helped the fire spread, narrow streets of the City allowing flames to move quickly from house to house, and great numbers of highly inflammable products (such as oil, spirits, fuel, tallow) kept in storage houses along the river bank, which would burn for days.

The Great Fire lasted until the $5^{\text {th }}$ of September. It devastated 87 of the existing 109 churches (including St. Paul's Cathedral), burned 52 livery company halls ${ }^{19}$, numerous civil administration buildings

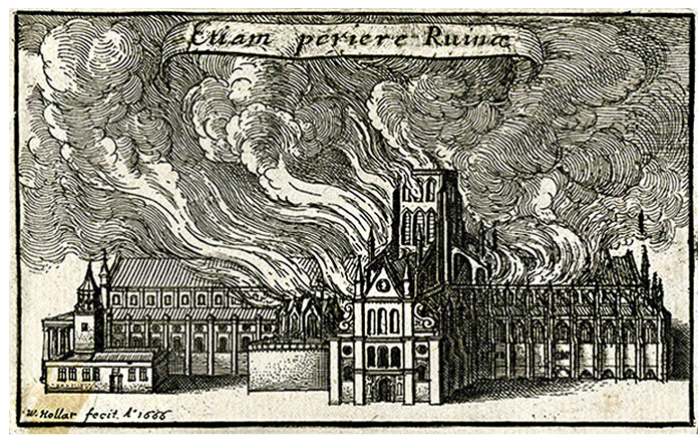

Fig 1. Old St Paul's Cathedral burning in the Great Fire, etching by Wenceslaus Hollar, in possesion of the British Museum

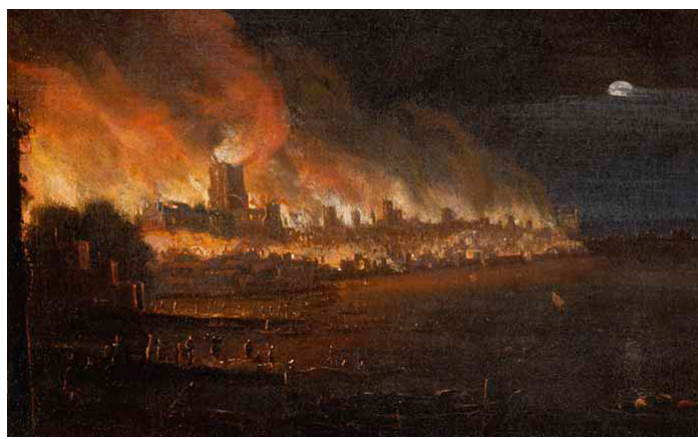

Fig. 2. An anonymous oil painting of the Great Fire, the view taken from the West

and courts, totally obliterating the city infrastructure and making around 100000 people homeless (fig. 1). It levelled approximately 436 acres of space. In the words of a British historian: '[Fire] laid waste five sixths of the walled area of the medieval city, from Fleet Street in the west to the Tower of London in the east, and north from the bank of the Thames to the wall at Cripplegate. [...] Within the area of the fire no buildings survived intact

19 Data given in the Rebuilding Act 1666, https://www.parliament.uk/about/ living-heritage/transformingsociety/towncountry/towns/collections/collectionsgreat-fire-1666/1666-act-to-rebuild-the-city-of-london/ [accessed: 10.02.2019]. 
above ground.[...] In many places the ground was too hot to walk on for several days afterwards ${ }^{20}$.

One of the eye-witnesses of the great blaze was Samuel Pepys, a civil servant in the position of Secretary of the Navy Board and a diarist, who noted on the $2^{\text {nd }}$ September 1666:

[...] and there staid [= I stayed] till it was dark almost, and saw the fire grow; and, as it grew darker, appeared more and more, and in corners and upon steeples, and between churches and houses, as far as we could see up the hill of the City, in a most horrid malicious bloody flame, not like the fine flame of an ordinary fire. [...] We staid till, it being darkish, we saw the fire as only one entire arch of fire from this to the other side the bridge, and in a bow up the hill for an arch of above a mile long: it made me weep to see it. The churches, houses, and all on fire and flaming at once; and a horrid noise the flames made, and the cracking of houses at their ruins ${ }^{21}$.

Three days later, when the fire was still raging, Pepys writes:

I up to the top of Barking steeple, and there saw the saddest sight of desolation that I ever saw; every where [sic!, original spelling] great fires, oyle-cellars, and brimstone, and other things burning. I became afeard to stay there long, and therefore down again as fast as I could, the fire being spread as far as I could see it; [...] Fanchurch-streete, Gracious-streete; and Lumbard-streete all in dust. The Exchange a sad sight, nothing standing there [...]. Walked into Moorefields (our feet ready to burn, walking through the towne among the hot coles). [...] Thence homeward, having passed through Cheapside and Newgate Market, all burned, and seen Anthony Joyce's House in fire. And took up (which I keep by me) a piece of glasse of Mercers' Chappell in the streete, where much more was, so melted and buckled with the heat of the fire like parchment.

Describing the panic among Londoners and their attempts to save whatever they could, as well as all actions undertaken to stop the fire

${ }^{20}$ http://www.bbc.co.uk/history/british/civil_war_revolution/after_fire_01. shtml [accessed: 10.02.2019].

${ }^{21}$ S. Pepys, Diary, https://www.pepysdiary.com/diary/ [accessed: 21.03.2019]. All subsequent citations from Pepys's Diary are from the same website. 
from spreading, Pepys comments on the prevailing atmosphere of a great catastrophe and his own distress. The choice of phrases - such as: 'with my heart full of trouble', 'a lamentable fire', 'rage every way', 'home with a sad heart', 'every body discoursing and lamenting the fire', 'so great was our fear' - testifies to the overwhelming sensation of a great calamity (fig. 2). The experience must have been truly traumatic. Various diary entries in the year 1667 speak of Pepys's problems with sleep and recurring nightmares. However, the English collective memory of the Great Fire much less preserved the image of tragedy and loss and much more a vision of London's victory and resurrection.

\section{THE GREAT FIRE OF LONDON: SYMBOLIC ASPECT}

In the debate about the meaning of the Great Fire, which started straight after its first night, conflicting theories and explanations vied for public attention. On the one side of the political spectrum there appeared voices that the fire was deliberately started by Catholic conspirators who wished to destroy a Protestant city. As illustrated by the anonymous publication Pyrotechnica Loyolana, the blame was put on Jesuit arsonists ${ }^{22}$. Pepys recorded in his Diary how it suddenly became dangerous to speak French in London and how a Frenchman was eventually found guilty of arson and consequently put to death at the scaffold. History proved that he was an innocent lunatic. Samuel Rolle published a pamphlet entitled Shilhavtiya or the Burning of London in the Year 1666, where he included an illustration of God's appearance over London in the form of long serpents of fire and where he claimed that 'many Romanists have been very jocund and full

${ }^{22}$ The book, whose full title is Pyrotechnica loyolana, ignatian fire-works; or, the fiery jesuits temper and behaviour, printed in 1667, is in the British Museum. Its description on the Museum website states: 'Most of the blame for the Great Fire was put onto Catholics. London was a Protestant city and many people feared that Catholics in England would help foreign armies invade the country and force the population to convert to Catholicism. They saw the fire as a Catholic plot. Anti-Catholic books were written for many years, even though the fire was declared an accident in January 1667'. https://www.museumoflondonprints.com/ image/379215/pyrotechnica-loyolana-ignatian-fire-works-or-the-fiery-jesuitstemper-and-behaviour-1667 [accessed: 10.02.2019]. 


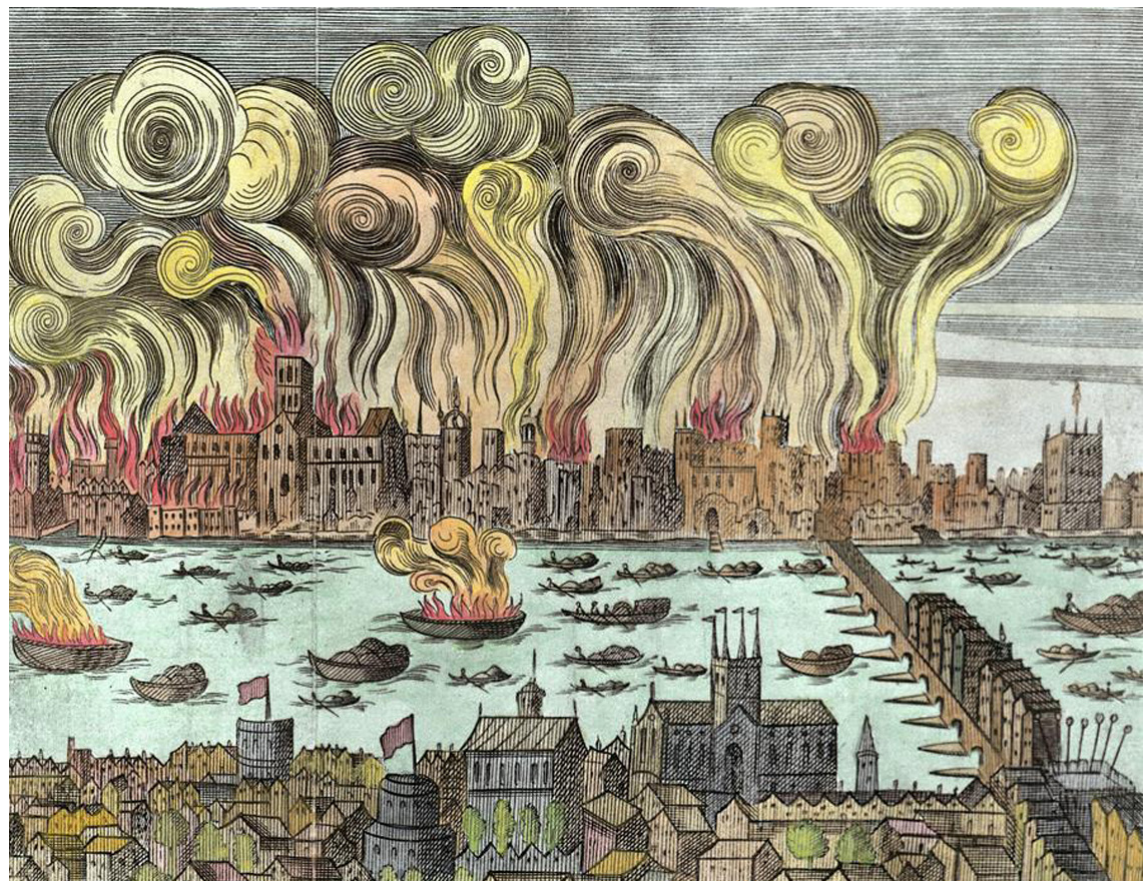

Fig. 3. Samuel Rolle's illustration to his Shilhavtiya or the Burning of London in the Year 1666

of triumph since that Fire', adding that the convicted Frenchman's confession revealed that 'he was instigated by Papists' (fig. 3). There were also theories propagated by anti-royalist Puritan preachers who interpreted the Fire as God's punishment for sins. God's anger was believed to have been caused by lax morals and hedonistic practices of the Court.

Trying to make sense of the disaster often resulted in viewing it as one in a long series of seventeenth century tragedies: the Civil War and the Commonwealth (1642-1660), the Great Plague of 1665, and the war with Holland of the same year. But it was the explanation of the catastrophe put forward by monarchists and supporters of King Charles II Stuart which proved to be the longest-lasting and dominant, the one that presented the Fire as an act of cleansing and a golden opportunity for a new London. The Great Fire acquired its symbolic meaning as a purifying force and a harbinger of a fresh start. A number of factors combined to guarantee the future success of such an interpretation: the King's personal involvement in giving 
assistance to fire fighting, his Declaration addressed to Londoners and his subsequent speech in Parliament, decisions concerning the rebuilding of London with the position of the Surveyor General offered to architect Christopher Wren, and the popularity of John Dryden's poem Annus Mirabilis.

On $16^{\text {th }}$ September the King issued 'His Majesty's Declaration to His City of London', where he presented the Fire as a chance for London's future development, symbolically depicting the great disaster as a necessary stage to a larger good. The King spoke about future London which will 'rather appear to the world as purged with Fire [...] to a wonderful beauty and comeliness $^{23}$. Especially significant seems the King's choice of the verb 'purge', widely circulated in medical and religious discourse. It brings to mind an unpleasant but much needed therapy, a painful remedy which will bring a desired effect ${ }^{24}$. Christoph Heyl argues that 'the royal proclamation floated the idea that God had merely used the fire to clear space for a new, much more beautiful and magnificent London' 25 . The early suggestion that the Fire might prove beneficial in the long run was strengthened by two artistic expressions fulfilling the role of the media of national memory - Annus Mirabilis by John Dryden, poet, playwright and translator, and a man 'who knew well how to adapt himself to the varying modes of his time ${ }^{26}$, and the Monument to the Great Fire erected in the City.

\section{ANNUS MIRABILIS: A YEAR OF WONDERS 1666}

Consisting of 304 quatrains, Dryden's longest poem ever written, created in 1667, refers to two important events in English history - a war with Holland (or in fact a series of naval battles against the Dutch), and the Great Fire of London. The verse is addressed to London itself, 'the metropolis

${ }^{23}$ Quoted after: Ch. Heyl, op. cit., p. 124.

${ }^{24}$ For a lengthy discussion on Charles II's declaration as royal propaganda see: ibidem.

25 Ibidem, p. 125.

26 D. Daiches, A Critical History of English Literature (2 ${ }^{\text {nd }}$ edition), Vol. 3: The Restoration to 1800, London 1968, p. 544. 
of Great Britain ${ }^{27}$, its Latin title as well as its English subtitle announcing a certain, partly ambiguous, interpretation of history based on the polysemy of the word 'wonder'. As a noun, 'wonder' may refer to something surprising and difficult to believe, or something unusually beautiful causing admiration. It may also mean God's miracle. Thus, in Dryden's intention, the year 1666 could be viewed as 'miraculous' in a triple sense - it brought curious and strange happenings; it gave reason for bewilderment, awe, and appreciation; and it also manifested God's intervention in human life. In his apostrophe to London, Dryden emphasizes his praise for the city, drawing attention to two meanings of 'a wonder/wonders': 'To you, therefore, this Year of Wonders is justly dedicated, because you have made it so. You, who are to stand a wonder to all Years and Ages, and who have built yourselves an Immortal Monument on your own Ruins. You are now a Phoenix in her ashes'. The third meaning - of God's miracle - will be disclosed by the poet in verse.

Out of 304 stanzas, 211 are devoted to the Dutch war, with the remaining 97 dealing with the Great Fire in three clearly outlined themes: 1. the fire itself and how it affected Londoners; 2 . the role of the King in commanding relief and sketching the rebuilding plans; 3 . the vision of a new London, reborn after the disaster. As explained in the invocation, the poet's wish is as much to present 'a history of destruction' as to provide a prophesy of the capital's restoration.

Using anthropomorphisation Dryden presents fire as a monster and a 'mighty murderer', who getting stronger with every step walks boldly with his head held high, moving in the direction of the royal palace, helped on his way by the winds compared to 'crafty courtesans'. Devouring everything that stands in its way, the fire resembles a hundred-head Hydra and a lawless usurper.

The King, awoken from his sleep and deprived of his rest, personally gives orders and commands the rescue operation. With his 'tender' breast pierced by the shrieks of Londoners, with his 'sacred' face illuminated by sparks of fire, and with tears running down his cheeks, he perseveres in

27 J. Dryden, Annus Mirabilis, in The Poems of John Dryden, London 1914, https://www.bartleby.com/204/5.html [accessed: 26.03.2019]; all subsequent citations from this site. 
his effort, knowing that 'Subjects may grieve, but Monarchs must redress'. The sovereign's presence gives hope to distressed people, who 'Think Life a Blessing under such a King'. In utmost despair, the monarch turns to God:

Or, if my heedless Youth has stept astray,

Too soon forgetful of thy gracious hand;

On me alone thy just Displeasure lay,

But take thy Judgments from this mourning Land.

Answering the royal prayer, in His grace the Almighty makes a miracle, sending to Earth a winged messenger to extinguish the blaze and save the city.

In stanza 276 Dryden repeats the phrase 'purged with/by fire', previously used by Charles II in his Declaration to the City of London, now imbedded in the context of God's decision, stating: 'But, since it was prophan'd by Civil War, Heav'n thought it fit to have it purg'd by fire'. In this way, the poet not only further disambiguates the title, referring as he does to God's divine intervention, but also explains why the Almighty punished Londoners. It was the outbreak of the Civil War with all its bloodshed, an ungodly, 'profane' deed, which demanded chastisement. The verse hints indirectly at the execution of Charles I (father of Charles II) as a great sin and reason for God's anger ${ }^{28}$.

Foreseeing future, Dryden depicts London in 'a nobler frame', rebuilt according to a new plan, more spacious and 'deified'. In one of the most often quoted fragments we read:

Me-thinks already, from this Chymick flame,

I see a city of more precious mold:

Rich as the town which gives the Indies name,

With Silver pav'd, and all divine with Gold.

New London, emerging from the ashes, adopts the form of a woman, previously a modest shepherdess, now a beautiful maid wooed by suitors. Compared to 'a Maiden Queen' (an obvious allusion to the powerful

28 One of the most important events of the English Civil War of 1642-1651 was the trial and execution of Charles I and subsequently the exile of his son, future King Charles II. 
monarch Elizabeth I and the time of England's greatness), London reborn will be prosperous and glorious, powerful and invincible. The Great Fire created an opportunity for the King's loyal subjects to create a city that would be a wonder of Europe. They need strength, industriousness, courage and loyalty, but they will prevail.

Annus Mirabilis - largely a piece of propaganda and a panegyric on royal virtues - shows how to turn disaster into triumph. Simultaneously, the poem illustrates how a recycled interpretative version of a historical fact may with time achieve the status of myth. The story of a victorious London arising again, codified in verse by the King's loyal subject and historiographer (very soon, in 1668, to become Poet Laureate), was a few years later enshrined in stone, when Dryden's symbolic interpretation of fire as a new beginning received further force in the form of the Monument of the Great Fire of London erected in the heart of England's capital.

\section{THE MONUMENT}

The Monument of the Great Fire of London ${ }^{29}$ (popularly known simply as the Monument) is a tall (about $62 \mathrm{~m}$, i.e. 202 feet) Doric column in the antique tradition, designed by Christopher Wren and Robert Hooke ${ }^{30}$ and erected in the City at the distance of $62 \mathrm{~m}$ from the original bakery where the Fire started (fig. 4). The pillar, situated on a plinth, is topped with an orb (originally copper now gilded, also referred to as 'urn' or 'vase') from which emerge golden flames (fig. 5). Constructed in the years 1671-1677, the Monument was meant to preserve the memory of the Great Fire both as a catastrophe and an opportunity/promise for a new London. The decision to build an appropriate monument was taken by Parliament. The Rebuilding of London Act (properly called 'An Act for Rebuilding the City of London'), drawn up in 1666 and passed in February 1667 states: 'And the better to preserve the memory of this dreadful Visitation, be it further enacted, that a Column or

${ }^{29}$ For the factual information about the Monument see: https://www.themonument.info/history/sculpture.html [accessed: 14.02.2019].

30 Most sources mention both architects as co-authors. P. Glanville maintains that the true designer was R. Hooke and Ch. Wren's role was minimal. See: P. Glanville, The City of London, [in:] The Cambridge Cultural History of Britain, ed. B. Ford, Vol. 4: Seventeenth-Century Britain, Cambridge 1992, p. 173. 


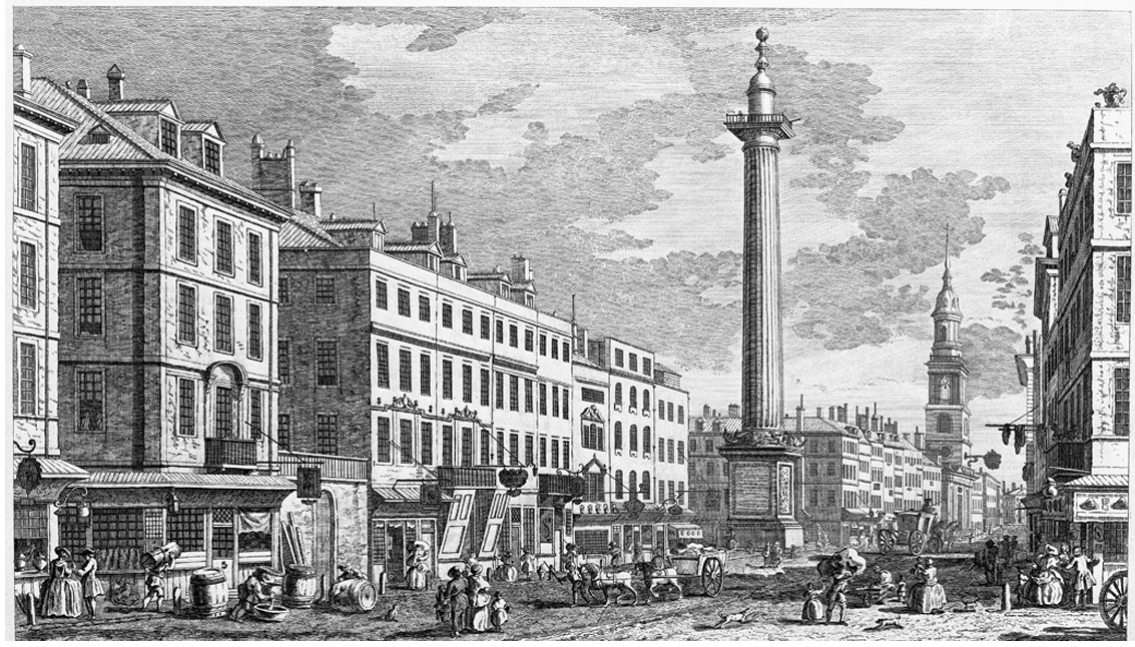

Fig. 4. Monument in 1741, engraving by Giovanni Antonio Canaletto

Pillar of Brass or Stone be erected on or as near unto the place where the said Fire so unhappily began, as conveniently maybe, in perpetual Remembrance ${ }^{31}$. The Monument commemorates the destruction of London and forecasts the city's restoration both in letters and in sculpture ${ }^{32}$. The plinth of the column is inscribed on three sides with text in Latin and

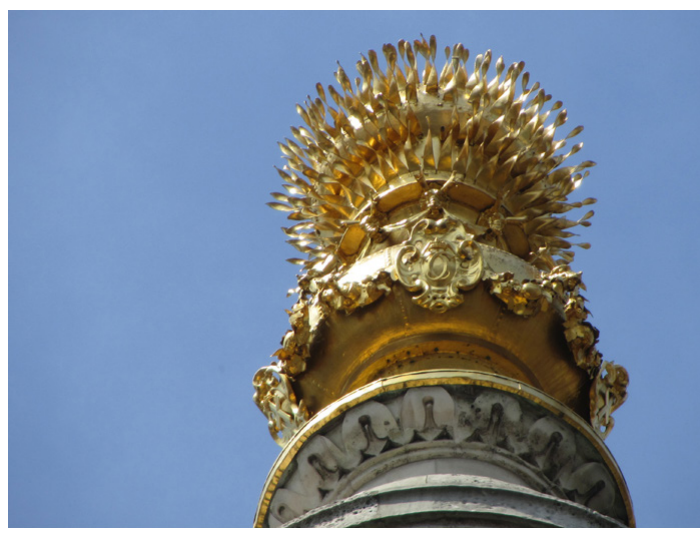

Fig. 5. The flaming orb of the Monument (photograph: Suzy Verrian) its English translation.

31 Rebuilding of London Act 1666, XXIX, https://www.morrlaw.com/wp-content/uploads/partywall/rebuilding-of-london-act-1666.pdf [accessed: 10.02.2019].

32 For a detailed explanation of all symbols see: https://www.themonument. info/history/sculpture.html [accessed: 10.02.2019]. 


\section{THE MONUMENT}

THE MON IN CONSULTATION WITH SIR CHRISTOPHER WREN. THE MONUMENT DESIGNED BY ROBERT HOOKE FRS IN CONSULTAT HILL. TO COMMEMORATE THE GREAT WAS BUILT 1671-1677. ON THE SITE OF ST MARGARET FISH STRER. DEVASTATING TWO-THIRDS OF THE FIRE OF LONDON 1666. THE FIRE BURN 7 CHURCHES. AND 52 LIVERY COMPANY HALLS

CITY. AND DESTROYED IS. THE MONUMENT. A FREESTANDING FLUTED DORIC COLUMN TOPRD FROM THE SITE OF THE BAKERY IN 61 M/202FT IN HEIGHT, BEING EQUAL TO THE DISTANCE WEST SHAFT ORIGINALLY HOUSED LENSES FOR A PUDDING LANE WHERE THE FIRE BROKE OUT. ITS CEN RAL SHAF ORIGINALLY HOUSE OF 311 STEPS ZENITH TELESCOPE. AND ITS BALCONY. REACHED BY AN INTERNAL SPIRAL STAIRCASE OF AFFORDS PANORAMIC VIEWS OF THE CITY. THE ALLEGORICAL SCULPTURE ON THE PEDESTAL ABOVE WAS EXECUTED BY CAIUS GABRIEL CIBBER AND SHOWS CHARLES I COMING TO ASSIST THE SLUMPED FIGURE OF THE CITY OF LONDON.

\section{ST MAGNUS THE MARTYR}

FISH STREET HILL. TO THE SOUTH, LEADS TO ST MAGNUS THE MARTYR. A WREN CHURCH, ALONGSIDE WHICH IS THE ANCIENT STREET WHICH LED TO THE MEDIEVAL LONDON BRIDGE.

\section{www.themonument.org.uk}

Fig. 6. Information on the Monument (photograph: Suzy Verrian)

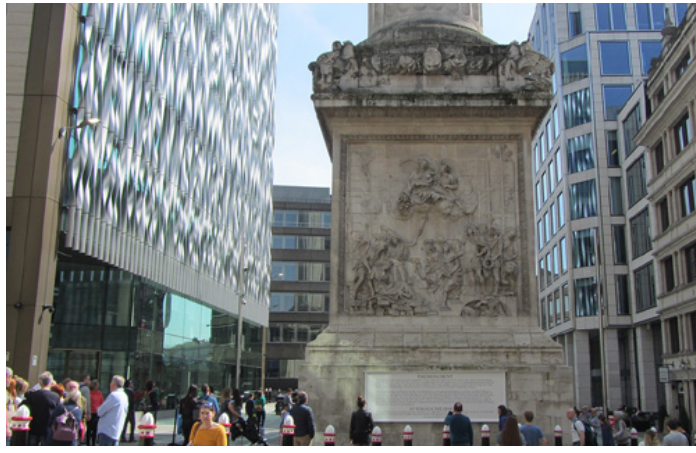

Fig. 7. Caius Gabriel Cibber's plinth (photograph: Suzy Verrian)

The North side carries information about the fire itself, how it started, how much damage it caused, and how it was eventually extinguished (fig. 6). The role of King Charles II in fighting the blaze is described on the South side, and the history of building the Monument on the East. The West side features an allegorical relief by Caius Gabriel Cibber, which is dense with detail and meaning (fig. 7). Three separate parts may be distinguished. The left side shows a distressed female figure representing London, who is sitting among ruins in a pose of great despair. She is offered support by Time (a bald, winged figure) and Providence (fig. 8). On the right, facing this group, we can recognize King Charles II dressed in a Roman costume with a laurel wreath on his head, accompanied by his brother Duke of York (future King James II) (fig. 9). The Monarch offers protection to the desolate woman (the City of London) by commanding three figures (Liberty, Architecture and Science) to assist her. Above, two goddesses sitting in clouds present a cornucopia (denoting wealth 
and plenty) and a palm branch (standing for peace and triumph) (fig. 10). In the background, behind the downcast figure of London, one can discern Londoners among burning houses. At London's feet, partly hidden, there is a beehive (skep) representing industry/ industriousness.

Various authors, commenting on the Monument's allegorical message, drew attention to particular details. Robert Seymour observes that Cibber's sculpture presents in stone what the South side inscription reveals in words, i.e. praise of Charles II, who 'commiserating the deplorable state of things, whilft [whilst] the ruins were yet smoaking [smoking], provided for the comfort of his citizens, and the ornament of his city $^{\prime 33}$. John Noorthouck notes that the beehive shows that 'by industry and application the greatest misfortunes may be overcome ${ }^{34}$. An alternative (or additional) interpretation which could be offered, based on Christian symbolism, would read the beehive as denoting

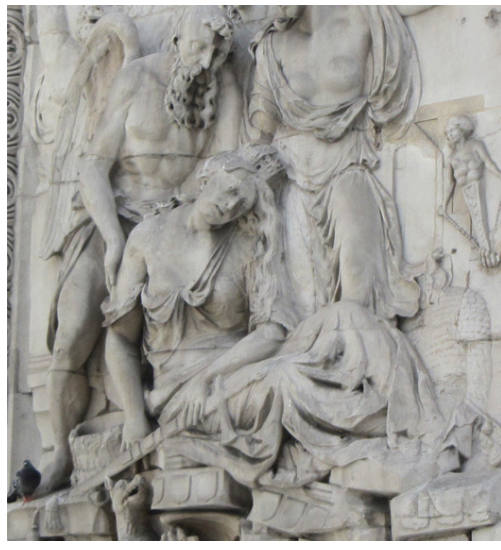

Fig. 8. The figure of a woman representing London (photograph: Samantha Verrian, cropped)

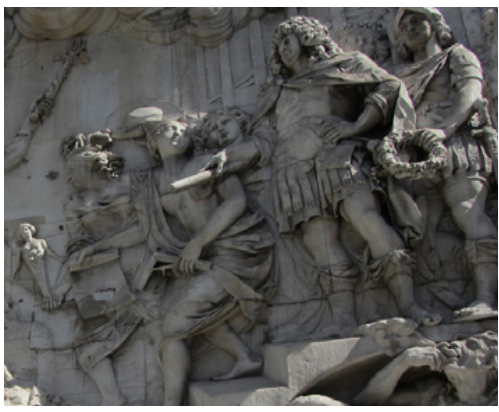

Fig. 9. King Charles II offering suport (photograph: Samantha Verrian)

${ }_{33}$ R. Seymour, A survey of the cities of London and Westminster, borough of Southwark, and Parts Adjacent, Vol. I, London 1733, p. 451-452, quoted after: http://vanderkrogt.net/statues/object.php?webpage=ST\&record=gblo154 [accessed: 10.02.2019].

${ }^{34}$ J. Noorthouck, A New History of London: Including Westminster and Southwark, (Book 2, Ch. 10), London 1773, quoted after: http://vanderkrogt.net/ statues/object.php? webpage $=$ ST\&record $=$ gblo154 [accessed: 10.02.2019]. 


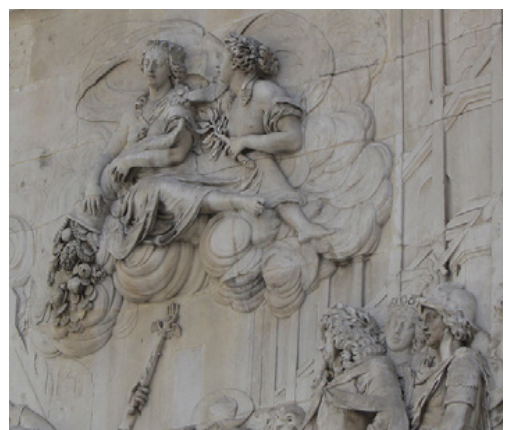

Fig. 10. Two goddesses with a cornucopia and a palm branch (photograph: Samantha Verrian)

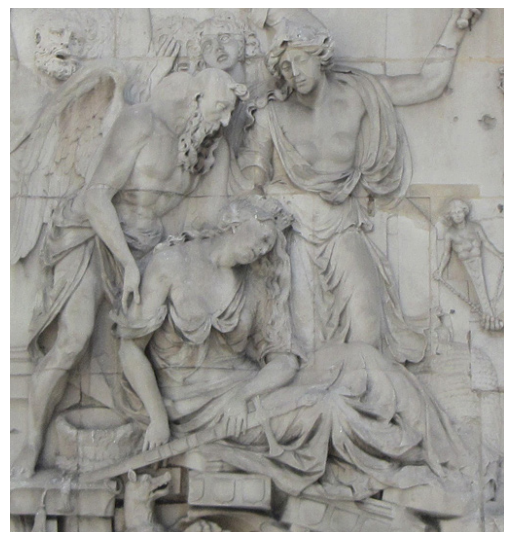

Fig. 11. The figure of Time (Kairos) (photograph: Suzy Verrian)

'a pious and unified community' ${ }^{35}$, which would highlight Londoners' common purpose and shared belief. Christoph Heyl focuses on the figure of Time (fig. 11) stating:

This figure is bald, apart from a very prominent forelock. To classically educated viewers of the period, he would have been instantly recognizable as a representation of opportunity, of the right moment, of what ancient Greeks called the Kairos. The idea was that the Kairos suddenly appeared in front of you. You had to seize him by the forelock immediately or else he would be gone [...]. Here the idea of the fire as a golden opportunity was carved in stone ${ }^{36}$.

Thus, telling the story of the Great Fire and promising the rebuilding of the City according to the rules of science and art, the Monument also highlights civic virtues indispensable to future success: hard work, perseverance, communal effort in the atmosphere of peace and liberty, fortitude and loyalty. In this way, memory of a historical event becomes interwoven with a sense of shared values, while the possibility of triumphant success depends on deeds undertaken in unison - by the King and his subjects.

${ }^{35}$ G. Ferguson, Signs and Symbols in Christian Art, London - New York 1961, p. 12.

36 Ch. Heyl, op. cit., p. 131-132. 
Interestingly, the North side inscription on the Monument, informing about the causes/effects of the Great Fire, unlike Cibber's allegorical relief, did not last in its original form for centuries to come. In 1680, the then Lord Mayor of London ordered a new inscription to be added, signifying that 'the City of London was burnt and consumed with fire by the treachery and malice of the papists' ${ }^{37}$. The reason was explained as 'for the extirpating the protestant religion, and English liberties, and to introduce popery and slavery ${ }^{38}$. Next year it was followed by the sentence: 'But Popish frenzy, which wrought such horrors, is not yet quenched' ${ }^{39}$, reviving the conspiracy theory about Catholic arsonists and hinting at brewing danger. The line was removed four years later after the accession of Catholic James II, only to reappear again with the reign of Protestant William of Orange. It remained chiselled in stone until 1830, a year after the Catholic Emancipation Act of $1829^{40}$.

The history of the Monument's modifications proves how tempting for the powers that be is manipulation of collective memory and how memory's appropriation serves political purposes. Each monument, by definition, is a medium of memory. Behind its creation lies a conviction that a particular historical event deserves a special place in public consciousness, that it should be commemorated. Designed and built at particular moments, monuments give evidence to social needs and moral values of the time of their creation. Simultaneously, they possess a certain symbolic agency inherently connected with a society's sense of its identity. "Designed to be permanent, the actual monument changes constantly as it renegotiates ideals, status and entitlement, defining the past to affect the present and the future"st. The Monument of the Great Fire of London, with all its symbolic connotations, remains subject to a range of possible significations.

${ }^{37}$ Ch. Welch, History of the Monument, London 1921, p. 24.

38 Ibidem, p. 25.

39 Ibidem.

40 Ibidem, p. 28.

${ }^{41}$ R.S. Nelson, M. Olin, Introduction, [in:] Monuments and Memory, Made and Unmade, eds. R.S. Nelson, M. Olin, Chicago - London 2003, p. 7. 


\section{$350^{\text {TH }}$ ANNIVERSARY OF THE GREAT FIRE}

The memory of the Great Fire was also regularly revived during anniversaries. As was the custom of Protestant England, 'the traditional annual cycle of holy days was [...] gradually replaced by a new calendar based on recent historical events, not the feast days of long-dead saints ${ }^{42}$. The Rebuilding Act of 1666 decreed in its special paragraph XXVIII entitled 'A Solemn Fast yearly in Memory of the Desolation' that $2^{\text {nd }}$ September be 'a day of Public Fasting and Humiliation within the said City [...], to implore the Mercies of Almighty God upon the said City, to make devout Prayers and Supplication unto Him to divert the like Calamity for the time to come ${ }^{43}$. However, as years went by, prayer and fasting gave way to spectacle. In Victorian England it was public entertainment offered by the Royal Surrey Gardens in London that proved especially popular. Among various extravagant re-enactments of historic events two most famous celebrations were the eruption of Vesuvius and the Great Fire of London.

In 2016, the $350^{\text {th }}$ anniversary of the event was celebrated on a large scale. The Museum of London had prepared a major interactive exhibition called Fire! Fire! and launched a specially designed Minecraft computer game, while Art Collective Artichoke, together with the City of London, staged a fewday-long festival with presentations and talks, whose greatest attraction was a show on the Thames called London's Burning. A 120-metre-high wooden replica of the seventeenth century London was raised on a special barge afloat in the Thames and on the evening of $4^{\text {th }}$ September 2016 it was publically burned, with flames projected onto St. Paul's Cathedral (fig. 12-13). Thus, the festival culminated in a great conflagration watched by thousands, if not millions, since it was broadcast live.

Journalists covering the celebrations in the media, as well as various interviewees, spoke about the Great Fire as 'an iconic moment in the city's history from which modern London emerged'44, the fire which 'paved

${ }^{42}$ P. Sherlock, The Reformation of Memory in Early Modern Europe, [in:] Memory: Histories, Theories, Debates, op. cit., p. 38.

43 Rebuilding of London Act 1666, op. cit., XXVIII.

${ }^{44}$ S. Ament [in:] M. Brown, Museum of London to mark the Great Fire of London, "Guardian”, $2^{\text {nd }}$ Sept. 2015, https://www.theguardian.com/culture/2015/sep/02/museum-of-london-to-mark-great-fire-of-london [accessed: 15.01.2019]. 


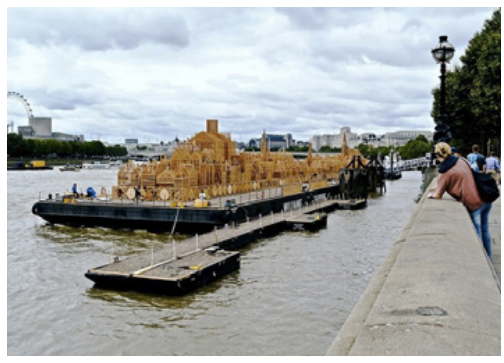

Fig. 12. Wooden replica of the seventeenth century London

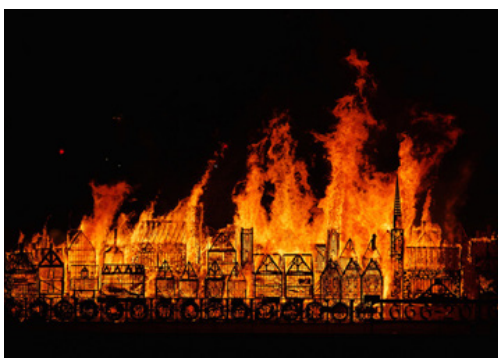

Fig. 13. London's Burning $-350^{\text {th }}$ anniversary of the Great Fire

the way for the building of the modern city' ${ }^{45}$, which 'devastated the capital and forced it into a rebirth' ${ }^{36}$, and which 'shaped the London we know now'47. Much attention was given to 'the London of today [...] built from the ashes of the wooden city' ${ }^{48}$, 'the capital's resilience [which] helped it rebuild and survive' 49 , 'the great city we enjoy today [which managed to] rise from those ashes, develop and thrive' 50 , 'the resilience of London and its people in rebuilding their City ${ }^{51}$, and 'the city's ability to rebuild and thrive ${ }^{52}$.

The above quotations show a uniformly consistent view and a striking singularity: the collective memory of the Great Fire of London is that of a chance for a new beginning. In the speakers' choice of lexis (e.g. 'pave

${ }^{45}$ https://www.theguardian.com/uk-news/2016/sep/05/wooden-replica-of -17th-century-london-burnt-to-the-ground-on-great-fire-anniversary [accessed: 15.01.2019].

${ }^{46}$ Ch. Lytton, T. Ough, London's Burning. Again, „The Telegraph”, $2^{\text {nd }}$ Sept. 2016, telegraph.co.uk/graphics/projects/london-great-fire-burning-art/index.html [accessed: 15.01.2019].

47 Ibidem.

48 https://www.theguardian.com/uk-news/2016/sep/05/wooden-replica-of -17th-century-london-burnt-to-the-ground-on-great-fire-anniversary [accessed: 15.01.2019]

49 Ibidem.

50 Ibidem.

${ }^{51}$ https://www.museumoflondon.org.uk/discover/creating-fire-fire [accessed: 15.01.2019].

${ }^{52}$ Ch. Lytton and T. Ough, op. cit. 
the way for...', or 'force into a rebirth') we can easily hear the strongly resounding echo of King Charles II's Declaration of 1666 and his phrase 'purged with fire for a wonderful beauty and comeliness'.

In its symbolic multivalency fire offers a plethora of possible interpretations. A metaphor for divinity, a sign of light (hence illumination and enlightenment), warmth and beauty (hence the family hearth) or, conversely, a destructive force and eternal punishment (Hell), fire embraces both good and bad. But the memory of the Great Fire of London is not so much of destruction as of transmutation and resurrection. In its symbolic aspect of a lieu de mémoire the seventeenth century catastrophe stands for regeneration. Speaking to „The Telegraph”, Helen Marriage, Artichoke director, notes: 'I think fire is very deep in our society [...]. It really is about letting things go and seeing it go up in smoke - it's a very powerful metaphor ${ }^{53}$.

Seemingly, the festivities of the $350^{\text {th }}$ anniversary of the Great Fire recycle a well-established myth. A great disaster is commemorated yet again with the same narration of London's resilience, emphasising how the building of the new capital started from scratch. However, the forms of commemoration adopted in the year 2016 differ markedly from earlier acts of remembrance. Meriel Jeater, the curator of Fire! Fire! stresses that the Museum's ambition is creating 'not just an exhibition, but an experience ${ }^{554}$, so that visitors could get 'the sense of walking into another time ${ }^{355}$. Privileging the physical and sensual aspects (over intellectual) points to present-day practices of treating the body as a medium (or stimulus) of memory.

In his influential book How Societies Remember (1989), Paul Connerton writes about embodied memory as an example of the cultural memory of a group. While explaining how recollected knowledge of the past is conveyed through commemorative celebrations, he draws attention to public 'acts of transfer' ${ }^{56}$, during which the past becomes communally re-enacted. Such acts bring together an individual and a group, providing a stage for a shared moment of remembering, for remembering in common

${ }^{53}$ H. Marriage, [in:] ibidem.

${ }^{54}$ https://www.museumoflondon.org.uk/discover/creating-fire-fire [accessed: 15.01.2019].

55 Ibidem.

56 P. Connerton, How Societies Remember, Cambridge 1989, p. 39. 
through bodily experience (sight, sound, movement, the thermal sensation of warmth/heat).

Experience of a truly corporeal character was guaranteed by London's Burning - an instance of modern cultural performance in both John McKenzie's ${ }^{57}$ and Diana Taylor's ${ }^{58}$ understanding. A performance act, by definition, involves symbols and life bodies to engage with societal arrangements. It either upholds existing norms and values, or resists them in an act of transgression, providing opportunity in which a social group may reflect upon its identity, define or re-define itself, and re-consider its history and collective myths. In this way, a performative act 'provides a way to constitute meaning and affirm individual and cultural values ${ }^{59}$; while at the same time 'constituting memory and consolidating identities ${ }^{60}$. The artist who stood behind London's Burning was David Best, the American sculptor who specializes in burning structures as part of Burning Man Temples festivals. Best creates wooden installations throughout the world, selecting such sites which have been affected by natural disaster or a community conflict (e.g. Northern Ireland). The act of burning a sculpture aims at collective reflection and acceptance, paying respect to victims and coming to terms with tragedy. Participants are invited to remember through celebration, as the structure is burned 'in a cathartic ritual to inspire healing and community ${ }^{36}$.

The novel character of the 2016 anniversary of the Great Fire is especially conspicuous in the link created between past and present which focuses on modern-day London in a wider sense than just on its rebirth to a 'wonderful beauty and comeliness'. „The Telegraph's” journalists state: 'The aim of the London's Burning festival is not just to relive the horror, but to reflect: on how the fire shaped the London we know now and to recognise the problems that face the city centuries on - not least, when parts of the city were in flames

57 J. McKenzie, Perform or Else: From Discipline to Performance, London - New York 2001, p. 29.

58 D. Taylor, The Archive and the Repertoire. Performing Cultural Memory in Americas, Durham - London 2007, p. 3.

59 J. McKenzie, op. cit., p. 31.

${ }^{60}$ D. Taylor, op. cit. p. XVIII.

${ }^{61}$ https://davidbesttemples.org/ [accessed: 15.01.2019]. 
during the riots of $2011^{\prime 62}$. And Helen Marriage adds: 'The people displaced 350 years ago are being displaced now. The economy is doing a topsy turvy thing on the people of London. The lower classes are being pushed out not by a fire, but by an economic fire ${ }^{363}$. Such comments suggest that the 2016 commemorations tried to modify the symbolic meaning of the Great Fire of London so that it would also encompass its aspect of human tragedy, the tragedy of individual Londoners, rather than the City as such. In this context, London's Burning spectacle as an example of performance art could fulfil the role of 'a catalyst to personal and social transformation' ${ }^{64}$.

Acts of remembrance rely on various media of memory and through ages new forms of commemoration have emerged. Performance, when viewed as a form of transmitting knowledge through embodied action, stands in stark contrast to 'archival memory' ${ }^{655}$ (i.e. documents, archaeological remains, monuments, films, literature, etc.). Taylor stresses the obvious fact that since performance requires presence ${ }^{66}$, it can only come to life when people participate in the production and transmission of meaning. As such, knowledge and embodied memory transmitted through performance can never be captured by 'archival memory', which separates 'the source of knowledge from the knower ${ }^{367}$, unlike performance which stands for individual agency. Classifying various types of the media of memory, Taylor proposes a basic distinction between 'the archive and the repertoire ${ }^{368}$, with performance belonging to the latter. As she maintains, the repertoire enacts embodied memory in multiple forms which transmit histories in expressive behaviour, consolidating identities and cultural values.

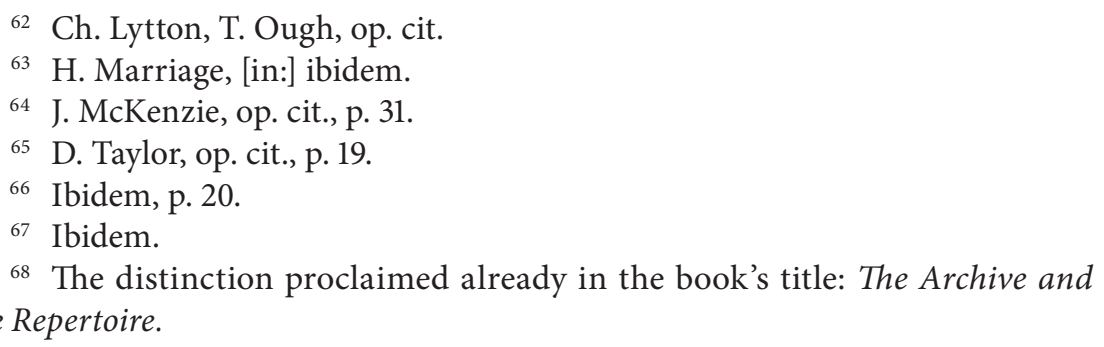




\section{THE GREAT FIRE OF LONDON: FUNCTIONAL ASPECT}

As the above discussion illustrates, the Great Fire of London as a lieu de mémoire has performed diverse social and cultural functions. Although the earliest feats of commemoration (Dryden's Annus Mirabilis, numerous tracts, ballads and pamphlets, as well as the Monument with its changing message) often aimed at stigmatizing the culprits or legitimizing the existing order, at the same time they appealed to commonly shared values (courage, valour, resilience, strength, industriousness, fortitude, etc.) and a sense of community. We may then distinguish here an important function of identity-building and forging a sense of belonging. Subsequently performed acts of remembrance, such as: celebrating the Fire's anniversaries, placing memorial plaques in various locations in London with the information about destroyed churches and houses, including the history of the Great Fire in the National Curriculum, regular publications of the historical/factual and fictional character ${ }^{69}$, and a constant renewal and re-fashioning of the media of memory applied in the process of memorialization (printed word, film, interactive exhibition, audio-visual ecological project ${ }^{70}$, performance) - all this strengthened a view of history as a continuum and enhanced a sense of national heritage. The past as lived experience forms a vital part of a group's understanding of who they are, giving meaning and purpose to their present-day existence.

Contemporary United Kingdom is a multicultural society with a conspicuous record of imperial legacies present in everyday encounters with the country's troubled past. "Domestic" British history of Anglo-Scottish and Anglo-Irish relations seldom finds an established national mode of interpreting the past. Likewise, it is not always easy to work out a consensus on how historical facts should be remembered and commemorated. Creating

69 There are dozens of such publications. Some of the more popular non-fictional books are: The Phoenix: St. Paul's Cathedral and the Man Who Made Modern London (2008) by Leo Hollis, The Rebuilding of London after the Great Fire (1940) by T.F. Reddaway. As for poetry and novels, especially noteworthy see: London in Flames, London in Glory: Poems of the Fire and Rebuilding of London 1666-1709 (1943), ed. R.A. Aubin, and Restoration (1989) by R. Tremain.

70 See: T. Schmidt, Unsettling Representation: Monuments, Theatre and Relational Space, „Contemporary Theatre Review” 2010, Vol. 20, No. 3, p. $283-295$. 


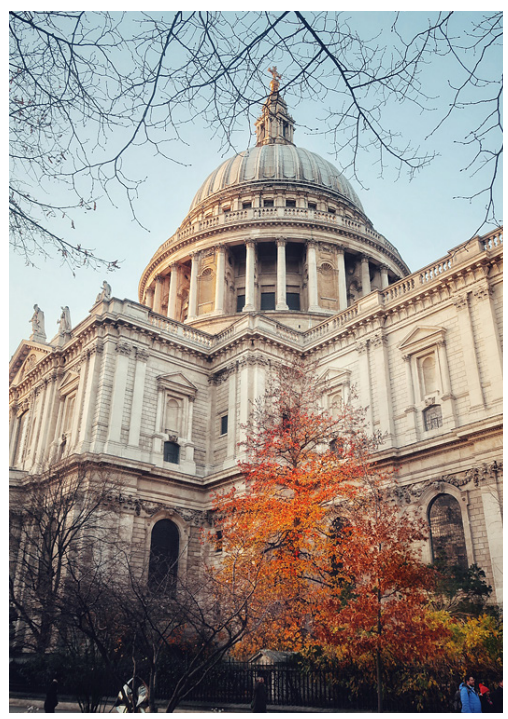

Fig. 14. St Paul's Cathedral designed by Sir Christopher Wren (photograph: George Hiles)

an impression that selected events of the nation's history may act as bricks and mortar in social consciousness and cohesiveness, simultaneously providing an anchor in the fast changing world, leads to stability. In the collective memory of the British, the Great Fire of London plays the role of a great bonding mechanism. It links individual with societal, past with present, destruction with resurrection, history with myth, the physical with the spiritual, the perishable with the immortal, and the history of the capital city with the history of the country. As a memory site, the Fire is a bastion of London's myth of its invincibility and the nation's determination to preserve it.

A single all-encompassing example of myth-building in service of patriotic feeling and nationhood is a story of London's St. Paul's Cathedral. Destroyed during the Great Fire, it was rebuilt according to a new design by Christopher Wren (fig. 14). Erecting the majestic, monumental church in the City of London took over thirty years and the construction is meant to remind the visitors of the great conflagration of 1666. The south portico off Cannon Street features a sculpture/relief by Caius Gabriel Cibber of the Phoenix rising from the flames above an inscribed slab. Peter Ackroyd ${ }^{71}$ recounts how in 1675 Wren asked an illiterate builder to bring a stone fragment from the heap of rubble of the old cathedral. The man chose a chipped memorial plate of an old tombstone that carried a single word 'Resurgam' (meaning 'I shall rise again'). Combined with Cibber's image, the Latin verb became an epitome of London's rebirth. When the City burned on 29 December 1940, after German bombs repeatedly hit London during the Blitz,

${ }^{71}$ P. Ackroyd, Londyn: biografia, transl. T. Bieroń, Poznań 2011, p. 771. 
and the Cathedral was severely damaged, 'the image of the dome with its cross held high above the tumultuous smoke and the glare of flame was seared into Londoners' imagination: the image of survival'72. The 1940 photograph of Wren's magnificent dome towering over destruction became

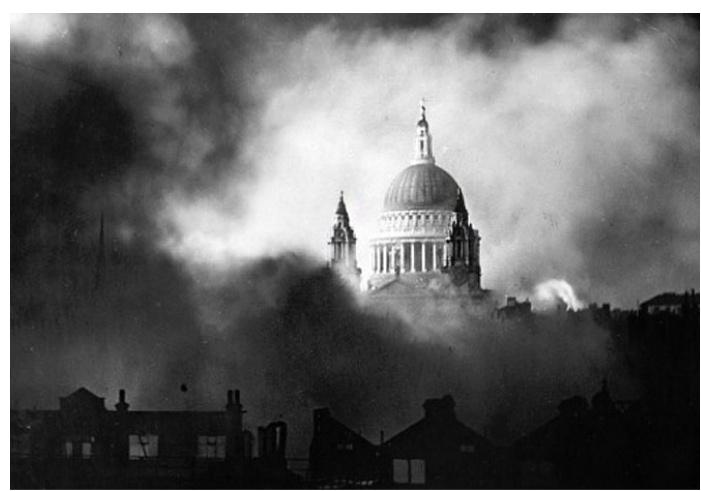

Fig. 15. St Paul's Cathedral during the 1940 blitz an iconic representation of hope against the odds. In Rutherfurd's London we can read: 'It was an awesome sight. Somehow, Wren's mighty, leaden dome remained intact. All around, the burning roofs created a surrounding lake of red, from which the massive temple of London arose dark, immovable, silent, with a rocklike indifference. It was as if [...] the old cathedral was declaring that even Hitler's Blitz could never touch the City's ancient heart and soul'73 (fig. 15).

The myth of 'the unconquerable capital and its indomitable people ${ }^{74}$ received a new boost.

\section{CONCLUDING COMMENTS}

Analysing the international career of the term 'sites of memory', Andrzej Szpociński insists that Nora's concept should be used 'only when events, people and cultural artefacts are seen in collective memory as depositaries [...] of not one particular value, but of matters important to the community in general'75, and 'based on intergenerational bonds' ${ }^{76}$. The Great Fire of London fulfils these requirements. In its time it affected individuals and

72 D. Piper, The Companion Guide to London ( $7^{\text {th }}$ edition), Woodbridge 1992, p. 356.

73 E. Rutherfurd, London, New York 1998, p. 1113-1114.

74 J. Paxman, The English. A Portrait of a People, London 1999, p. 86.

75 A. Szpociński, op. cit., p. 249.

76 Ibidem, p. 250. 
the whole community, while its memory survived through collective acts of remembrance, which were constantly modified and updated following the expectations of changing epochs. As a memory site, the event assumes the role of a cementing factor and identity builder, testifying to a certain specificity and unity of the group. The list of virtues and admirable character traits praised by Dryden in Annus Mirabilis and subsequently symbolically carved in stone in the Monument has never gone out of fashion as a firmly rooted ideal, even when, at times, it risked being turned into a caricature.

The lasting appeal of memory sites is predicated on meanings attached to them by earlier generations and a possibility of adapting these meanings to suit the living, which the event of the Great Fire as a lieu de mémoire exemplifies. Discussing commemoration practices at memory sites, Jay Winter observes that commemorative acts arise 'out of a conviction, shared by a broad community, that the moment recalled is both significant and informed by a moral message ${ }^{37}$. Again, clearly so, the Great Fire provides a good example of a social agreement about its historical significance and a lesson for the future. As I have argued elsewhere, we feel the need to cherish and defend memory sites because 'without our commemorative vigilance they would be quickly swept away ${ }^{78}$. Likewise, they could easily become political instruments to serve particular interests. The history of the Monument's vanishing inscriptions proves well that what is enshrined in stone does not always stand the test of time. Significantly, it also manifests the fact that when a consensus has been reached about an event's meaning, such an event may be commemorated regardless of whoever is in power.

Szpociński argues that continued relevance of memory sites has much to do with 'a particular sensitivity of contemporary culture ${ }^{79}$ and, specifically, with the emergence of two phenomena - theatricalization and visualization of culture, and consequently of memory sites. Theatricalization is understood as a growing number and role of various performances and happenings,

77 J. Winter, Sites of Memory, [in:] Memory: Histories, Theories, Debates, op. cit., p. 313.

78 A.M. Tomczak, Cultural Memory and Food: South Asian Diasporic Fiction, Białystok 2012, p. 224.

79 Ibidem, p. 245. 
whereas visualization refers to the dominant role of visual aspects in re-living the past. I believe the changing ways in which the Great Fire of London has been remembered through centuries illustrate the said phenomena perfectly well.

Nora's idea of lieu de mémoire, when used as a conceptual tool, makes it possible to link collective memory and identity not through a linear historic narration of a society's past, but through specific individual events and their symbolic impact. As a social construct, collective memory, based on shared remembering, is an important constitutive element of national identity. For British society, the Great Fire of London is one of its pillars.

\section{The author wishes to thank Suzy, Samantha and Pip Verrian for their great help} in obtaining the sources and photographs.

\section{Bibliography}

Peter Ackroyd, Londyn: biografia, transl. T. Bieroń, Zysk i S-ka, Poznań 2011.

Mark Brown, Museum of London to mark the Great Fire of London, „Guardian”, $2^{\text {nd }}$ Sept. 2015, https://www.theguardian.com/culture/2015/sep/02/museum -of-london-to-mark-great-fire-of-london.

Paul Connerton, How Societies Remember, Cambridge University Press, Cambridge 1989.

David Daiches, A Critical History of English Literature (2 ${ }^{\text {nd }}$ edition), Vol. 3: The Restoration to 1800, Secker \& Warburg, London 1968.

John Dryden, Annus Mirabilis, in The Poems of John Dryden, London 1914, https:// www.bartleby.com/204/5.html.

George Ferguson, Signs and Symbols in Christian Art, Oxford University Press, London - New York 1961.

Jacob F. Field, London, Londoners and the Great Fire of 1666: Disaster and Recovery, Routledge, London 2017.

Philip Glanville, The City of London, [in:] The Cambridge Cultural History of Britain, Vol. 4: Seventeenth-Century Britain, ed. B. Ford, Cambridge University Press, Cambridge 1992.

Christoph Heyl, A Miserable Sight. The Great Fire of London (1666), [in:] Fiasko Scheitern in der Frühen Neuzeit: Beitraege zur Kulturgeschichte des Misserfolgs, eds. S. Brakensiek, C. Claridge, Transcript, Bielefeld 2015. 
Edward N. Hooker, The purpose of Dryden's Annus Mirabilis, „Huntington Library Quarterly"1946, Vol. 10, No 1.

Andreas Huyssen, Present Pasts: Media, Politics, Amnesia, „Public Culture” 2000, Vol. 12, No. 1.

Andreas Huyssen, Present Pasts: Urban Palimpsests and the Politics of Memory, Stanford University Press, Stanford 2003.

David Lowenthal, The Past is a Foreign Country, Cambridge University Press, Cambridge 2003.

Charlotte Lytton, Tom Ough, London's Burning. Again, „The Telegraph”, $2^{\text {nd }}$ Sept. 2016, telegraph.co.uk/graphics/projects/london-great-fire-burning-art/index. html.

Jon McKenzie, Perform or Else: From Discipline to Performance, Routledge, London - New York 2001.

Robert S. Nelson, Margaret Olin, Introduction, [in:] Monuments and Memory, Made and Unmade, eds. R. S. Nelson and M. Olin, University of Chicago Press, Chicago - London 2003.

Pierre Nora, Between Memory and History: Les Lieux de Mémoire, transl.

M. Roudebush, „Representations” 1989, No. 26, Special Issue: Memory and Counter-Memory.

Jeremy Paxman, The English. A Portrait of a People, Penguin Group, London 1999. Samuel Pepys, Diary, https://www.pepysdiary.com/diary/.

Edward Rutherfurd, London, Arrow Books, New York 1998.

Thereon Schmidt, Unsettling Representation: Monuments, Theatre and Relational Space, „Contemporary Theatre Review” 2010, Vol. 20, No. 3.

Bill Schwarz, Memory, Temporality, Modernity. Les Lieux de memoire, [in:] Memory:

Histories, Theories, Debates, eds. S. Radstone and B. Schwarz, Fordham

University, New York 2010.

Peter Sherlock, The Reformation of Memory in Early Modern Europe, [in:] Memory:

Histories, Theories, Debates, eds. S. Radstone and B. Schwarz, Fordham University, New York 2010.

Andrzej Szpociński, Sites and Non-Sites of Memory, transl. A. Warso, „Teksty Drugie" 2016, Vol. 1, Special Issue - English Edition.

Diana Taylor, The Archive and the Repertoire. Performing Cultural Memory in Americas, Duke University Press, Durham - London 2007.

Adrian Tinniswood, By Permission of Heaven: the Story of the Great Fire of London, Riverhead Books, London 2004. 
Anna Maria Tomczak, Cultural Memory and Food: South Asian Diasporic Fiction, Wydawnictwo Uniwersytetu w Białymstoku, Białystok 2012.

Anne Whitehead, Memory, Routledge, London - New York 2009.

Jay Winter, The Memory Boom in Contemporary Historical Studies, „Raritan” 2001, Vol. 21, No. 1.

Jay Winter, Sites of Memory, [in:] Memory: Histories, Theories, Debates, eds.

S. Radstone and B. Schwarz, Fordham University, New York 2010.

\section{Online sources}

http://vanderkrogt.net/statues/object.php?webpage=ST\&record=gblo154 .

http://www.bbc.co.uk/history/british/civil_war_revolution/after_fire_01.shtml. https://davidbesttemples.org/.

https://www.historylearningsite.co.uk/stuart-england/the-great-fire-of -london -of-1666/.

https://www.morrlaw.com/wp-content/uploads/partywall/rebuilding-of-london -act-1666.pdf.

https://www.museumoflondon.org.uk/discover/creating-fire-fire.

https://www.museumoflondonprints.com/image/379215/pyrotechnica-loyolana-

ignatian-fire-works-or-the-fiery-jesuits-temper-and-behaviour-1667.

https://www.parliament.uk/about/living-heritage/transformingsociety/townco-

untry/towns/collections/collections-great-fire-1666/1666-act-to-rebuild-the -city-of-london/.

https://www.theguardian.com/uk-news/2016/sep/05/wooden-replica-of-17th-cen-

tury-london-burnt-to-the-ground-on-great-fire-anniversary.

https://www.themonument.info/history/sculpture.html.

\section{Sources of figures}

Fig. 1. https://greatfireoflondon.net/st-pauls-cathedral/.

Fig. 2. https://www.museumoflondon.org.uk/discover/great-fire-london-1666.

Fig. 3. https://www.museumoflondon.org.uk/museum-london/event-detail?id= 73409.

Fig. 4. https://www.museumoflondon.org.uk/discover/three-myths-you-believe- about -great-fire-london.

Fig. 5-11. Author's private archive.

Fig. 12. https://londonist.com/2016/09/in-Fig.s-londons-burning-the-great-fire350-festival. 
Fig. 13. https://www.artichoke.uk.com/project/londons-burning/.

Fig. 15. https://unsplash.com/photos/ZR3RR-Qz3L0.

Fig. 16. https://londonist.com/london/art-and-photography/in-photos-st-paul -s-at-it-s-best.

\section{The Great Fire of London as a Memory Site (Lieu de Mémoire)}

The author approaches the Great Fire of London of 1666 as a memory site, using Pierre Nora's concept to analyse various forms and acts of remembrance of this historic event. Special attention is paid to John Dryden's poem Annus Mirabilis, fragments of Samuel Pepys's Diary, the architectural Monument of the Great Fire in the City of London, and the celebrations of the $350^{\text {th }}$ anniversary with its spectacular London's Burning festival. Nora's idea of lieu de mémoire, when used as a conceptual tool, makes it possible to link collective memory and identity, not through a linear historic narration of a society's past but through specific individual events and their symbolic impact. As a social construct, collective memory is an important constitutive element of national identity. The memory of the Great Fire - in its material, symbolic and functional aspects - fosters cultural identity of the British and the feeling of belonging.

Keywords: lieu de mémoire, Pierre Nora, Great Fire, London, Annus Mirabilis, John Dryden, Samuel Pepys, Monument 